\title{
Cytogenetic investigation in Saanen and Alpine artificial insemination bucks. Identification of a Robertsonian translocation
}

\author{
E Guillemot ${ }^{1}$, F Gary, HM Berland ${ }^{1}$, V Durand ${ }^{2}$, \\ R Darré ${ }^{1}$, EP Cribiu ${ }^{2 *}$ \\ 1 Ecole Nationale Vétérinaire de Toulouse, \\ Laboratoire INRA de Cytogénétique, \\ 23, chemin des Capelles, F 31076 Toulouse Cedex; \\ ${ }^{2}$ Institut National de la Recherche Agronomique, \\ Laboratoire de Cytogénétique, Centre de Recherche de Jouy, \\ 78352 Jouy-en-Josas, Cedex, France
}

(Received 21 June 1991; accepted 23 July 1991)

\begin{abstract}
Summary - The cytogenetic study of 224 AI Saanen and Alpine he-goats revealed the presence of a Saanen animal carrying a Robertsonian translocation. The chromosomes involved in this translocation were determined using G (GTG) and C (CBG) banding techniques. The chromosomes in question were identified as chromosomes 6 and 15 .

goat / chromosome / Robertsonian translocation

Résumé - Étude cytogénétique des boucs d'insémination artificielle de races Saanen et Alpine. Mise en évidence d'une translocation robertsonienne. L'étude cytogénétique de 224 boucs d'insémination artificielle de races Saanen et Alpine a permis de mettre en évidence la présence d'un animal de race Saanen porteur d'une translocation robertsonienne. Les chromosomes impliqués dans cette translocation ont été déterminés à l'aide des techniques de marquage $G(G T G)$ et $C(C B G)$. Les chromosomes concernés sont le 6 et le 15 .
\end{abstract}

caprin / chromosome / translocation robertsonienne

\footnotetext{
* Correspondence and reprints
} 


\section{INTRODUCTION}

In domesticated species, numerical chromosome aberrations are readily eliminated by natural selection, whereas structural abnormalities may give rise to polymorphic systems whose deleterious effects on fertility have been established in cattle (Gustavsson, 1969; Refsdal, 1976; Kovacks and Csulky, 1980). In goats, the most widespread structural aberrations are Robertsonian translocations (Cribiu and Lherm, 1986). Since these translocations are widespread in the Saanen breed (Cribiu and Lherm, 1986), a cytogenetic survey of AI goats was conducted in two French AI centres.

\section{MATERIALS AND METHODS}

The cytogenetic investigation was carried out in three groups : i) 224 AI bucks (98 Saanen and 126 Alpine animals) housed at the "Union Nationale des Coopératives Agricoles d'Elevage et d'Insémination Artificielle Caprine" (CAPRI-IA) and at the "Station Expérimentale d'Insémination Artificielle Porcine et Caprine" (SEIA); ii) the parents : dam and sire of the abnormal buck; iii) 62 daughters of the abnormal he-goat reared on farms located in France.

Lymphocyte cultures were prepared by a standard whole blood technique (Grouchy et al, 1964), incubated at $37^{\circ} \mathrm{C}$ for $68 \mathrm{~h}$. Cells were spread on glass slides, flame-dried, and either stored unstained at room temperature, or stained for 10 min with a $4 \%$ Giemsa solution. Unstained slides were treated for G-banding (GTG) using the method of Seabright (1971) and C-banding (CBG) following the method of Sumner (1972).

The chromosomes were identified, paired and arranged according to the recommendations of the Reading Conference (1976) and ISCNDA (1989).

\section{RESULTS}

Out of a total of 224 AI bucks examined, one Saanen male has been found to carry a structural chromosome abnormality, whereas no numerical aberration has been detected. The frequency of abnormal carriers among the 98 AI Saanen bucks examined was $1.02 \%$. The G-banding technique (GTG) made it possible to identify the chromosomal pairs involved in this translocation as pairs 6 and 15, respectively (fig 1). The C-banding technique revealed the presence of two constitutive heterochromatin blocks in the pericentromeric region of the translocated chromosome (fig 2).

Among the parents of the translocated buck, the sire had a normal karyotype and the dam was heterozygous for the $6 ; 15$ Robertsonian translocation. The ancestors of the translocated dam were imported from Great Britain, Germany and Switzerland.

Among the 62 daughters of the heterozygous buck, 32 were found to be carriers of the $6 ; 15$ Robertsonian translocation in the heterozygous state and 30 had a normal karyotype. 


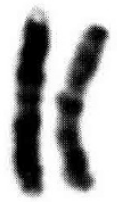

1

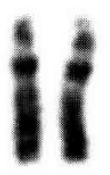

7

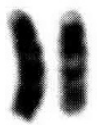

13

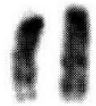

19

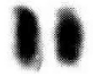

25
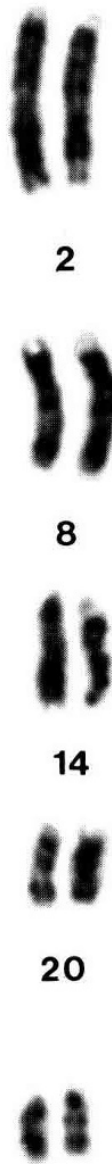

2

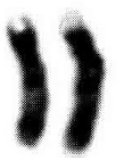

8

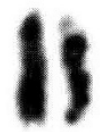

14

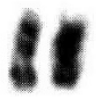

20

26

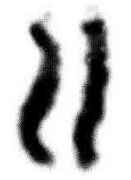

3

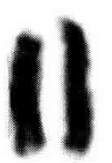

9

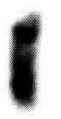

15

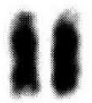

21

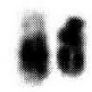

27

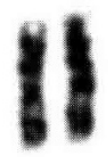

4

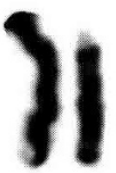

10

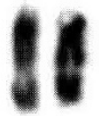

16

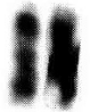

22

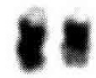

28

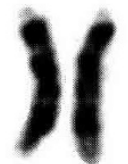

5

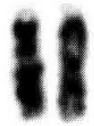

11

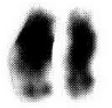

17

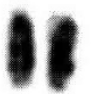

23

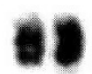

29

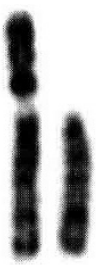

$6 / 156$

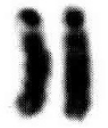

12

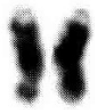

18

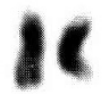

24

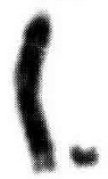

X Y

Fig 1. GTG-banded karyotype with the $6 ; 15$ translocation.

\section{DISCUSSION AND CONCLUSION}

Robertsonian translocations are the most frequently reported anomalies in domesticated bovidae. These translocations, also known as centric fusions, are named after Robertson (1916), who reported these rearrangements in the chromosomes of grasshoppers. Fifty years later, Padeh et al (1965) reported an unusual number of chromosomes $(2 n=59)$ in a hermaphrodite Saanen goat, and among the autosomes, a large submetacentric chromosome was noted. Further studies on Saanen goats reported a Robertsonian translocation similar to that reported by Padeh et al (1965) (Soller et al, 1966; Hulot, 1969; Padeh et al, 1971; Popescu, 1972; 


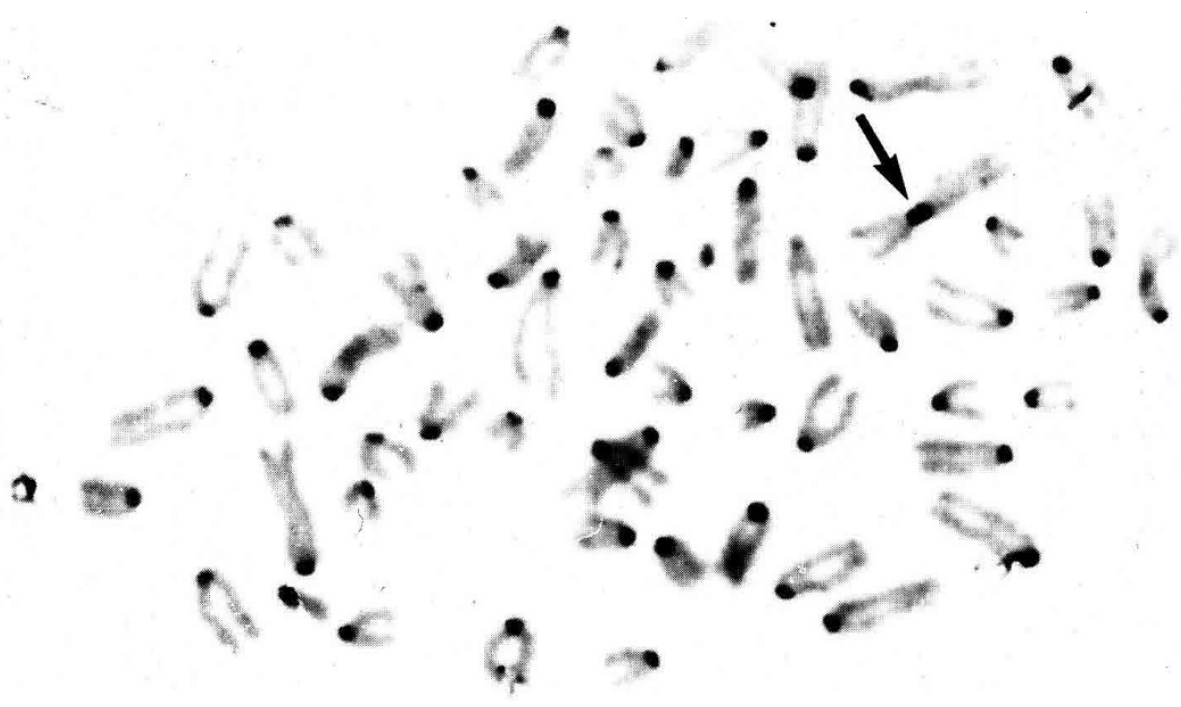

Fig 2. CBG-banded metaphase showing constitutive heterochromatin as two blocks in the $6 ; 15$ translocation (arrows).

Sohrab et al, 1973). Later cytogenetic investigations have permitted identification of the chromosomes involved; the submetacentric chromosome resulted from the fusion of autosomes 5 and 15 (Evans et al, 1973; Jorge, 1987), 6 and 17 (Elminger and Stranzinger, 1982) or 6 and 15 (Burguete et al, 1987; Yang et al, 1991). The comparison of the banding pattern of the $5 ; 15,6 ; 17$ and $6 ; 15$ translocations with that of the present paper permitted the conclusion that it is the same translocation. This translocation occurs at frequencies as high as $25 \%$ in some herds of Saanen goats in Brazil (Jorge, 1987). It has not been found in other breeds. Three other Robertsonian translocations have been detected in different breeds : a $3 ; 7$ translocation in Toggenburg (Dolf and Hediger, 1984), a 10;12 translocation in Malaga (Moreno and Franganillo, 1988) and a unidentified autosomal translocation in Murciana-Granadina (Burguete, 1991).

Robertsonian translocations result from the fusion of two acrocentric chromosomes. Three different mechanisms have been suggested for the formation of Robertsonian translocations from two acrocentric chromosomes, depending where the breakpoints are located. In the first case, one of the chromosomal breakpoints involves the short arms of one chromosome and the other is on the long arms of the second chromosome near the centromeric region. In the second case the breakpoints occur within the centromeres. In these two cases, the fusion gives rise to a monocentric meta- or submetacentric chromosome and a minute fragment containing the centromere which is lost during the subsequent cell divisions. In the third case, if the breakpoints involve only the short arms of both chromosomes in the centromeric region, the fusion leads to the formation of a dicentric meta- or submetacentric chromosome and loss of two acentric fragments. The use of the C-banding technique made it possible to suggest the mechanism by which this translocation arose: 
the $6 ; 15$ chromosome with two constitutive heterochromatin blocks in the pericentromeric region could be dicentric.

On the basis that structural chromosome anomalies, unlike recurrent genetic mutations, are unique events (White, 1968), this translocation seems to be transmitted as a Mendelian co-dominant trait. The origin of the translocation is uncertain, since the ancestors of the translocated he-goat come from Great Britain, Germany and Switzerland. Most cytogeneticists believe that the $6 ; 15$ translocation originated from Switzerland since the Saanen herds in which it was found have been constituted from animals coming from Switzerland (Hulot, 1969; Padeh, 1965; Popescu, 1972; Elminger and Stranzinger, 1982; Jorge, 1987).

As with a majority of Robertsonian translocations found in animal populations, the $6 ; 15$ translocation does not seem to be associated with phenotypic characteristics (Cribiu and Lherm, 1986). In the absence of fertility records, a reduced fecundity in heterozygotes resulting from anaphase I nondisjunction and/or changes in the pattern of recombination in such individuals, can not be excluded. An increased frequency of anaphase I nondisjunction has been reported in the laboratory mouse (Gropp and Winking, 1981) and the most widely studied chromosome translocation in cattle, the $1 ; 29$ Robertsonian translocation, showed reduced fertility in daughters of carrier bulls (Gustavsson, 1969; Refsdal, 1976).

\section{REFERENCES}

Burguete I (1991) Cytogenetic study on the Spanish "Murciano-Granadina" goat breed . In: Proceedings of the 9th Eur Colloq Cytogenet Dom Anim (Echard G, ed), Toulouse, July 1990. Genet Sel Evol 23 (Suppl 1), 78s-80s

Burguete I, Berardino D, Lioi MB, Matassimo D (1987) Cytogenetic observations on a Robertsonian translocation in Saanen goats. Genet Sel Evol 19, 391-398

Cribiu EP, Lherm C (1986) Caryotype normal et anomalies chromosomiques de la chèvre domestique (Capra hircus). Rec Med Vet 162, 163-167

Dolf J, Hediger R (1984) Comparison of centric fusions in a Toggenburg and a Saanen goat. In: Proceedings of the 6th Eur Colloq Cytogenet Dom Anim (Stranzinger G, ed) Zurich, July 1984, 311-312

Elminger B, Stranzinger G (1982) Identification of a centric fusion in the G-banding karyotype of a Saanen goat. In: Proceedings of the 5th Eur Colloq Cytogenet Dom Anim (Succi G, ed) Gargnano (Milan), June 1982, 407-409

Evans HJ, Buckland RA, Sumner AT (1973) Chromosome homology and heterochromatin in goat, sheep and ox studied by banding techniques. Chromosoma 42 , 383-402

Gropp A, Winking H (1981) Robertsonian translocations: cytology, meiosis, segregation patterns and biological consequences of heterozygosity. Symp Zool Soc Lond 47, 141-181

Gustavsson I (1969) Cytogenetics, distribution and phenotypic effects of a translocation in Swedish cattle. Hereditas 63, 68-169

Grouchy J (de), Roubin M, Passage E (1964) Microtechnique pour l'étude des chromosomes humains à partir d'une culture de leucocytes sanguins. Ann Genet 7 , 45 
Hulot F (1969) Nouveau cas de fusion centrique chez la chèvre domestique (Capra hircus). Ann Genet Sel Anim 1, 175-176

ISCNDA (1989) International System for Cytogenetic Nomenclature of Domestic Animals (Di Berardino D, Hayes H, Fries R, Long S, eds). Cytogenet Cell Genet $53,65-79$

Jorge W (1987) Cytogenetics of a chromosome translocation in goats. Proceedings of the IV International Conference on Goats, March 1987, 2, 1340

Kovacks A, Csulky S (1980) Effect of the 1/29 translocation upon fertility in Hungarian Simmental cattle. Proceedings of the 4 th Eur Colloq Cytogenet Domest Anim, Uppsala, June 1980, 35-43

Moreno M, Rodero-Franganillo A (1988) Estudio citogenetico de cabras hermafroditas de la raza Mallaguena. Archivos de Zootecnia, 37, 97-102

Padeh B, Wysoki M, Ayalon N, Soller M (1965) An XX/XY hermaphrodite in the goat. Israel J Med Sci 398, 1008-1012

Padeh B, Wysoki M, Soller M (1971) Further studies on a Robertsonian translocation in the Saanen dairy goat. Cytogenetics 10, 61-69

Popescu CP (1972) Mode de transmission d'une fusion centrique dans la descendance d'un bouc (Capra hircus L). Ann Genet Sel Anim 4, 355-361

Reading Conference (1980). Proceedings of The First International Conference for the Standardization of Banded Karyotypes of Domestic Animals, Reading 1976 (Ford CE, Pollock DL, Gustavsson I, eds). Hereditas 92, 145-162

Refsdal AO (1976) Low fertility in daughters of bulls with 1/29 translocation. Acta Vet Scand 17, 190-195

Robertson WRB (1916) Chromosome studies. I Taxonomic relationships shown in the chromosomes of Tettigidae and Acrididae. V-shaped chromosomes and their significance in Acrididae, Locustidae and Gryllidae: chromosomes and variation. $J$ Morphol 27, 179-331

Seabright M (1971) A rapid banding technique for human chromosomes. Lancet 2, 971-972

Sohrab M, McGovern PT, Hancock JL (1973) Two anomalies of the goat karyotype. Res Vet Sci 15, 81-87

Soller M, Wysoki M, Padeh B (1966) A chromosomal abnormality in phenotypically normal Saanen goats. Cytogenetics 5, 88-93

Sumner AT (1972) A simple technique for demonstrating centromeric heterochromatin. Exp Cell Res 75, 304-306

White MJD (1968) Models of speciation. Science 159, 1065-1070 